POSTPRINT: Inclusive education policy provision in South African research universities

Please note: This is a postprint version of the following article:

Ramaahlo, M., Tönsing, K. M., \& Bornman, J. (2018). Inclusive education policy provision in South African research universities. Disability and Society, Early online. https://doi.org/10.1080/09687599.2018.1423954

\title{
Inclusive education policy provision in South African research universities
}

Maria Ramaahlo, Kerstin Monika Tönsing, \& Juan Bornman

Centre for Augmentative and Alternative Communication

University of Pretoria, South Africa

Corresponding author: $\quad \begin{array}{r}\text { Maria Ramaahlo } \\ \text { maria.ramaahlo@up.ac.za }\end{array}$

\section{Acknowledgements}

This work was supported in part by the University of Pretoria Postgraduate Research Support Grant 13415281.

\begin{abstract}
The 4-A Framework suggests that all inclusive education systems must be available, accessible, acceptable and adaptable. South Africa is committed to establish an inclusive education system that does not exclude students with disabilities. South African university disability policies translate the imperatives of the United Nations Convention on the Rights of Persons with Disabilities into institutional mandates that govern the implementation of inclusive education. The aim of this study was to determine to what extent disability policies at South African research intensive universities addressed the markers contained in the 4-A Framework. The framework was reworked and operationalised for the higher education context, and expanded to include a fifth marker, namely affordability. A deductive thematic analysis, using a protocol based on the five markers, was used to analyse these policies. Results indicate that, of the five markers, affordability was not sufficiently addressed. Various disclaimers also limit policy provisions related to other markers.
\end{abstract}

Keywords: human rights education, inclusive higher education; policy analysis; provisions; students with disabilities; research intensive universities. 
POSTPRINT: Inclusive education policy provision in South African research universities

\section{Points of interest}

- There are key international human rights laws and policies that promote and protect inclusive education as a human right for students with disabilities. The human rights-based 4-A Framework suggests that inclusive education systems must be available, accessible, acceptable and adaptable.

- In South Africa, universities are required through their disability policies to promote the inclusion of students with disabilities.

- In order to understand the degree to which these policies adequately promote the inclusion of students with disabilities, the framework was reworked for the higher education context and expanded to include a fifth marker, namely affordability.

- A deductive thematic analysis, using a coding manual based on the 4-A Framework, was used to analyse disability policies of South African universities.

- Results show that whilst universities have made attempts in their policies to promote the inclusion of students with disabilities, affordability was not adequately addressed.

\section{Introduction}

Contemporary universities have evolved from serving a privileged few, to mass universal participation of individuals representative of the broader society (Powell 2013). This should include students with disabilities, especially since the international policy discourse for educating students with disabilities has moved towards inclusion (Tisdall and Riddell 2006). Under the auspices of the Convention on the Rights of Persons with Disabilities (CRPD) (United Nations 
POSTPRINT: Inclusive education policy provision in South African research universities 2006) Article 24 in particular, the development of inclusive education systems at all levels has become a legal obligation for ratifying states (Biermann 2016), placing the education of persons with disabilities within the human rights domain. This approach articulates well with the progressive rights-based legal framework that has been adopted in South Africa (one of the ratifying states) to prevent unfair discrimination (Howell, 2001). Thus, educational institutions are prohibited from discrimination against students based on disability. Within this framework, appropriate legislation (statutory law that is enforceable) and policy (documents that set out a course of action to be taken by a government or organization) and the effective implementation of such are assumed to become driving factors for inclusive education. Both the legislation (and/or policy) and its implementation therefore require scrutiny when studying the implementation of inclusive education within a particular sector and country. Since the implementers of any policy can only be held accountable to the mandates contained within the policy, the policy document itself assumes significance in its influence on implementation.

The internationally recognised 4 ' $A$ ' framework, which is conceptualised within a human rights domain, was developed by human rights activist and professor of law, Katarina Tomaševski (1999) during her term as Special Rapporteur of the United Nations High Commission for Human Rights (UNCHR) from 1998 - 2004. Tomaševski collaborated with various organizations during her term as rapporteur, such as the Swedish International Development Cooperation Agency, the Raoul Wallenberg Institute of Human Rights and Humanitarian Law at Lund University, the South Asian Human Rights Documentation Centre of New Delhi, the Rightslink of Columbia University in New York, the Committee on the Rights of the Child, as well as the International Programme on the Elimination of Child Labour of the International Labour Organization (Torres 2008). The 4-A Framework was first introduced in the 
POSTPRINT: Inclusive education policy provision in South African research universities 'Right to Education Primer 3' (Tomaševski 2001). This framework requires that inclusive education contexts must exhibit four essential markers, namely availability, accessibility, acceptability, and adaptability. Tomaševski (2001) asserted that the right to education is routinely classified as an economic, social, or cultural right, all of which are often deemed to be lacking remedies and are accordingly treated as quasi-rights. As a result, denial or the violation of the right to education is inadequately addressed. The 4 'A' Framework provides the clarity and specificity for addressing the right to education, particular for marginalised populations such as persons with disabilities, as it outlines governmental obligations to guarantee and realise the right to education (Tomaševski 2001; Schaeffer 2009). Tomaševski (2001) pointed out that the inter-relatedness of human rights creates overlap between the individual markers of this framework. As a result, she added indicators to the basic framework as examples of issues that figure prominently in translating the right to education from theory into reality. Schaeffer (2009) captured the elements of these indicators within the framework, including a modification of constitutional guarantees and policies, training of educators, curricula, instructional techniques, academic environments, support structures, social environments, resource allocation, and removal of social and attitudinal barriers in order to embrace diversity and difference.

Whilst the framework was not developed specifically for persons with disabilities, it has been utilised as a framework to evaluate the guidelines of provisions in state and institutional inclusive policies relating to persons with disabilities (Murungi 2013; Skelton 2013; Tesemma 2012). The 4 'A' Framework has been applied to the South African context by Tesemma (2012) to critically analyse legislature and policy on the basic education of children with disabilities in South Africa. Murungi (2013), in a comparative study of Kenya and South Africa, discussed the application of the 4 'A' Framework to the right to primary education of persons with disabilities. 
POSTPRINT: Inclusive education policy provision in South African research universities

The United Nations Educational, Scientific and Cultural Organization (UNESCO) Chair of Education Law in Africa, Ann Skelton (2013) utilised the 4 'A' Framework for the analysis of the role of the courts in ensuring the right to a basic education in a democratic South Africa.

Internationally, this framework has been used to analyse legislature and policy on the basic education of children with disabilities in Sweden and Scotland (Maxwell and Granuland 2011). Maxwell and Granlund (2011) conceptually reworked the 4 'A' Framework and added a fifth marker, affordability, to their analysis model.

The 4 'A' Framework has been critiqued for paying relatively little attention to higher education and the position taken with respect to these levels of education is unclear (Klees and Thapliyal 2007). Inclusive education is an on-going process and applying a human rights-based approach to education requires the development of a comprehensive model that addresses all aspects of the education system (Schaeffer 2009). Issues of availability, accessibility, acceptability and adaptability do not only apply to primary education but are equally important to consider in higher education, and in the policies, that govern this sector of education.

\section{Inclusive higher education in South Africa}

South African universities have responded to national efforts toward an inclusive education system. Bell (2013) postulates that the social model of disability has - in addition to a human rights framework - informed the development of inclusive disability policies in South Africa. Whereas the previously prevailing individual model of disability postulated that disability was the outcome of the impairment of a person and therefore needed to be addressed at this level (Shakespeare 1996; Oliver 1996), the social model advocates for the removal of socially constructed barriers (such as segregated education) 
POSTPRINT: Inclusive education policy provision in South African research universities

In South Africa, the inclusion of students with disabilities in higher education institutions is driven by several inclusive policies. The government's first attempt to address the lack of equity in higher education consisted of Education White Paper 3: Transformation of the Higher Education System, which the Department of Education gazetted in 1997 (Department of Education (DoE) 1997). The paper's stance is equal access and non-discrimination in an attempt to overcome past inequalities. Education White Paper 3 also advocated for the transformation of the institutional landscape with the provision that students with disabilities must be supported by the higher education system as a whole, as opposed to individual institutions (DoE 1997; FOTIM 2011). Complimentary to Education White Paper 3, the National Plan for Higher Education was released in 2001, and provides limited guidelines for the transformation of institutions and the higher education system (Department of Higher Education and Training [DHET] 2001).

Education White Paper 6: Special Needs Education, was gazetted by the DoE in 2001. It directly addressed inclusive education in the basic education system but only alluded to an inclusive higher education system. In recognition of support for students with disabilities, Education White Paper 6 recommended regional collaboration between universities when increasing access, participation and throughput of students with disabilities (DoE 2001). Regional collaboration refers to institutions admitting and providing specialised support only to students with certain categories of disabilities and excusing all others. Most recently, the Education White Paper on Post School Education (2013) directly addresses the inclusive higher education environment as it advocates for support for students with disabilities in the higher education system (DHET 2013). It acknowledges that there are gaps in the provisions of inclusive policies, as students with disabilities still experience discrimination and challenges with access, curriculum, student funding and student support (DHET 2013). At present, the only law that directly refers to 
POSTPRINT: Inclusive education policy provision in South African research universities inclusive practices in higher education is the Higher Education Act no.1 of 1997 (South Africa, 1997). This act stipulates that universities must redress past inequalities in their admissions policy so that no student is unfairly discriminated against.

In their discussion of White Paper 6, Donohue and Bornman (2014) noted that a lack of clarity in this document regarding the goals of inclusive education and the means by which these goals would be achieved is a significant factor in limiting policy implementation. Similar observations can be made about all the aforementioned national policies and legislation. National policies and legislation lack clarity on what provisions should be made for supporting students with disabilities at universities. These policies also lack implementation guidelines for the inclusion of students with disabilities at higher education institutions. Considering these limitations, individual higher education institutions have both the freedom and the responsibility to define and implement inclusive education at a tertiary level under the auspices of their internal policies. Disability policies at South African universities in particular play a significant role in this process (Ndlovu 2016). All research universities presently have disability policies aimed at ensuring the inclusion of students with disabilities at their institutions (Foundation of Tertiary Institutions of the Northern Metropolis [FOTIM] 2011; Heiman and Precel 2003; Sayed 2003).

While these legislative and policy developments seem a step in the right direction, actual enrolment figures of students with disabilities at South African universities are still extremely low, and are estimated to be at less than $1 \%$ of the total student population (FOTIM 2011). This proportion needs to be understood with reference to the national prevalence of persons with disabilities in South Africa. However, this data is not readily available due to the lack of consensus around defining disability. This impedes the ability to develop disability indicators (McLaren, Solarsh, and Saloojee 2003). Instruments used to measure disability in low and 
POSTPRINT: Inclusive education policy provision in South African research universities

middle-income countries typically lack specificity (ability to correctly identify those without impairments) and/or sensitivity (ability to identify those with impairment) (Cartwright and Carvounis 2005; Eide et al. 2011). According to the South African Census 2011, there is a national disability prevalence rate of $7.5 \%$. Considering international statistics, estimated at $15 \%$ (World Health Organisation [WHO] 2011) this prevalence seems low, especially considering that prevalence of disability in developing nations is typically higher.

Even without accurate prevalence data, a proportion of less than $1 \%$ of students with disabilities at South African universities suggests that there is as yet pervasive exclusion in this sector. Disparities in tertiary enrolment for students with disabilities are furthermore evident among the different population groups. Attendance is highest among the white population group and lowest among black African students (DHET 2015). These disparities stem from unequal provisions that were prevalent across all ministries, including education, during the apartheid era, which was marked by widespread exclusion in the areas of race, gender and disability (Pather 2011).

For students with disabilities, the inequalities in higher education begin with inequalities that have shaped the whole schooling system in South Africa (Howell 2001). Students with disabilities furthermore continue to face physical, social and attitudinal barriers when accessing higher education (Bell 2013; Lourens 2015). Numerous research and government reports on the experiences of students with disabilities in higher education in South Africa indicate that provision for students with disabilities is far from ideal, as these students confront restrictions to or exclusions from the curricula, assessment opportunities, social activities, built environment and financial resources (Bell 2013; Carrim 2002; Fitchett 2015; FOTIM 2011; Howell 2001; Lourens 2015; Matshedisho 2007; Ndlovu 2016; Swart and Greyling 2011; Watermeyer 2009). 
POSTPRINT: Inclusive education policy provision in South African research universities

While one may be tempted to ascribe this solely to poor implementation of disability policies of South African universities, the policy itself should be critically evaluated, since it sets the parameters of the provisions that students can expect and that policy implementers can be held accountable for.

This paper therefore sets out to analyse policy provisions in disability policies of South African tier 1 research intensive universities according to a human rights-based framework that outlines the five themes of inclusive higher education for students with disabilities, to understand the degree to which these policies adequately cover these themes. The internationally recognised 4 'A’ Framework by Tomaševski (1999) (availability, accessibility, acceptability and adaptability), which sets out the essential features of inclusive education in all its forms and levels, was used as a basis for developing the analytical framework. This framework was adapted for the higher education context to allow a systematic analysis and comparison of provisions set out in the respective disability policies across different institutions. Tier 1 research intensive universities were selected as they are amongst the most well-established higher education institutions known for their academic excellence, high levels of scholarship, economic activity and innovation, and international diversity (Times Higher Education 2017). In the South African context, these institutions have been known to have longstanding disability units and are generally able to provide students with a wide range of services (FOTIM 2011).

\section{Methodology}

To contextualise the analysis, this section provides a brief description of the five research intensive universities in South Africa. Thereafter, procedural details are given about the document selection. The theoretical underpinning and construction of the coding manual that 
POSTPRINT: Inclusive education policy provision in South African research universities

informed the data analysis is also discussed. This section culminates with a description of the data analysis.

\section{South African tier 1 research intensive universities}

There are currently 26 universities (including universities of technology) in South Africa, with a student cohort of 983,698 and a staff cohort of 50,090 (academic and support) (DHET 2015). Five of these universities comprise so-called 'tier one' education institutions in South Africa. A university is ranked as a tier 1 institution by the South African DHET ranking in accordance with South Africa's Centre for Higher Education Transformation (CHET). A tier 1 ranking is achieved when a university is research intensive (CHET 2012).

Tier 1 research intensive universities in South Africa vary in their historical backgrounds, these reflecting the racial divide of South Africa's past (Lourens 2015). Three of these institutions (referred to as University 1, 2 and 3 in this study) were recognised by the Apartheid government as 'whites only' institutions. They were therefore created to provide education and training for people designated as white and the medium of instruction was Afrikaans. In contrast, the fourth institution (University 4) accepted admissions from all racial categories. When racial segregation was enforced in 1959, this university maintained a stand against apartheid and was thus subject to campus invasions by riot police and saw their staff and students being banned, deported or detained (Council for Higher Education, [CHE] 2010). The last institution, University 5, the youngest of the top five universities, came into existence on 1 January 2004, following a merger between two universities. The merger was not pursued enthusiastically and was not warmly welcomed due to concerns raised of cultural incompatibility and loss of institutional memory, despite both institutions providing education and training predominantly 
POSTPRINT: Inclusive education policy provision in South African research universities

for people designated as Indian (Cebekhulu and Mantzaris 2006; Westhuizen 2011; Chetty and Merrett 2014). University 5 is currently recognised as a historically disadvantaged institution. Formerly white intuitions enjoyed the full wealth of South Africa's resources (FOTIM 2011; Howell and Lazarus, 2003; Matshedisho 2007). They still benefit from this historical advantage, and may therefore be more able to provide a wider range of services to their students. At the same time, their history of exclusionary practices may make them less likely to pursue inclusive policies.

\section{Document analysis}

Thematic analysis is a "method for identifying, analysing and reporting patterns within a data set" and is a flexible tool that can give a detailed and complex account of data (Braun and Clarke 2006). A deductive thematic analysis was used to categorise the provisions made in disability policies of research intensive universities according to the markers and indicators of the 4-A framework. The stages of data analysis were multi-tiered. First, a coding system was developed using the markers and indicators of inclusive education, which served as the coding system's themes for analysing the policies. This was followed by consensus coding of the disability policy of each of the tier 1 research intensive universities by the three authors.

\section{Development of the coding system}

The first author, with input from the second and third author, developed a coding system based on the four markers of inclusive education from the 4 'A' framework (Tomasevski 1999), with addition of a fifth marker, namely affordability, based on the work by Maxwell and Granlund 
POSTPRINT: Inclusive education policy provision in South African research universities

(2011). First, the five markers (which constituted the themes of the coding system) were operationally defined for the higher education context as follows:

Availability refers to the existence of education institutions and programmes that students with disabilities can apply to without restriction (Tesemma 2012; Howell 2001; DHET 2013). This is incompatible with the concept of 'regional collaboration' as suggested in the White Paper 6, as availability requires that all eligible students should be admitted to any institution. Furthermore, availability requires disability units to be established at the institution, as they play a central role in the inclusion of students with disabilities without restriction at these institutions (Lourens 2015; Matshedisho 2010).

Accessibility is based on the principle of non-discrimination and inclusion (Tomasevski 1999). Therefore, institutions must actively work to remove barriers that would prohibit students with disabilities to apply for and gain admission to the institution. This requires a proactive approach to accessibility, in which institutions must address structural and cultural barriers that exist that may restrict the opportunity of students with disability to gain entry. Howell and Lazarus (2003) argue that policy implementation and institutional transformation have placed limited attention on accessibility for students with disabilities. The physical, social, attitudinal barriers that students with disabilities experience as a result, substantially limit the ability of these students to gain access to higher education institutions.

Acceptability describes the institution's acceptance and recognition of students with disabilities as a part of the University community by indicating a willingness to engage with students with disabilities (to hear the student voice)., Tinklin, Riddell and Wilson ( 2004) postulate that a platform for the voices of students with disabilities is seldom found in inclusive 
POSTPRINT: Inclusive education policy provision in South African research universities policies and practices. Beauchamp-Pryor (2012) supports this notion by indicating that policy provisions should provide a platform for the voice of students with disabilities to be heard. Adaptability requires that institutions apply the Universal Design for Learning (UDL) approach (UN, 2016). The core elements of this principle in line with universal design principles are the flexibility of curricula, instructional techniques and assessment opportunities for the benefit of all students (Tomaševski 2004: vi). In a study by Ntombela (2013) on inclusive higher education environment and the experiences of students with physical disabilities, findings indicate the importance of not just access to the curriculum but access to social learning opportunities and the institutions support structures. Thus, an institution's academic support structures and its social environments should be conceived, designed and applied to meet and adjust to the requirements of every student. In addition, the institution is required to adapt and reasonably accommodate the needs of each individual student (Tomaševski 2004). According to UN (2016) the term 'reasonable' is understood as the result of the contextual test that involves the relevance and the effectiveness of the accommodation. Whilst the availability of resources and financial implication is considered when assessing disproportionate burden, the duty to provide reasonable accommodation is enforceable from the moment it is requested and must be considered in light of the overall obligation to develop an inclusive higher education system. UN (2016) asserts that using the lack of resources and financial crises as justification for failure to progress towards inclusive education is in direct violation of Article 24 of the CRPD (2006). Affordability, for this study, refers to the economic accessibility to educational services provided by the institution. During the Apartheid era there was a vast disparity in per capita funding in different education departments. Section 29 of the South African Constitution (1996) consists of a cluster of education rights, viewing basic education as a non-progressive right. 
POSTPRINT: Inclusive education policy provision in South African research universities

Thus, it entitles all persons, including those with disabilities, the right to a basic education, regardless of resource limitations. In addition, the right to education is extensively protected in international law, with Article 26 of the Universal Declaration of Human Rights (1948) if everyone has the right to free education at least in the elementary and fundamental stages, which guarantees free basic education to previously disadvantaged learners as a priority (United Nations 1948). The right to further education is qualified to the extent that reasonable measures (within available resources) must be made to achieve the progressive realisation of this right (Arendse 2011). In view of this, affordability is an important concept to include for an analysis of disability policy provisions in inclusive higher education policies of South African institutions.

As a second step, 17 policy indicators relative to the higher education context were identified, using the indicators by Tomasevski (1999) and Schaeffer (2009) as a basis. These indicators served as codes to further delineate availability, accessibility, acceptability, adaptability and affordability. Figure 1 below is a representation of the five markers (themes) and 17 policy indicators (codes) developed for the coding system. 
POSTPRINT: Inclusive education policy provision in South African research universities

Figure 1. Derivation of markers and indicators

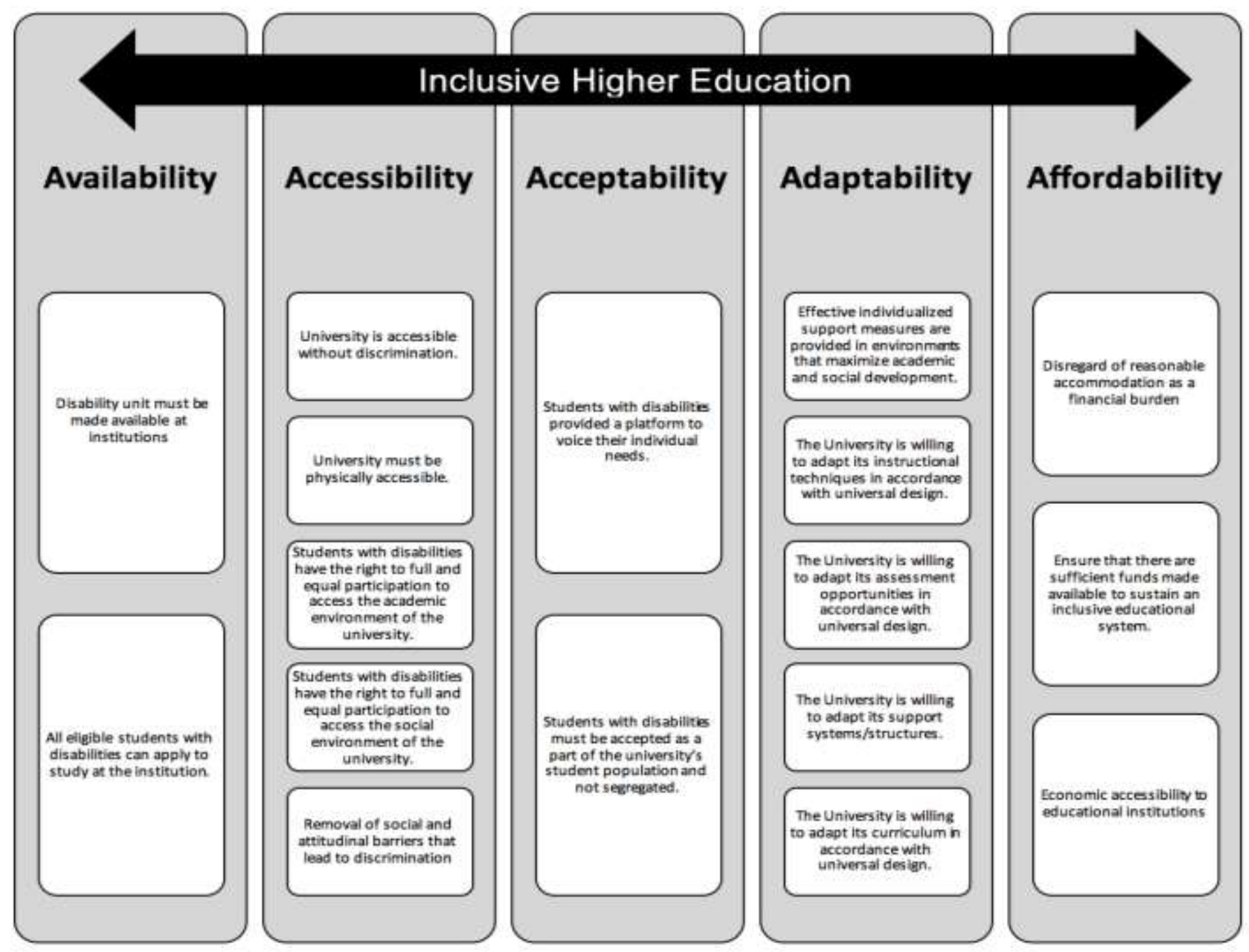

The coding system was subjected to two rounds of expert reviews. The panel of the expert review comprised ten researchers in the field of disability studies, with eight members possessing a Master's degree qualification and two members with a Doctoral degree qualification. The panel conducted a blind allocation of the 17 indicators (to be used as codes) to the five markers. The indicators address the following: instructional techniques, academic environments, support structures, social environments, universal design, resource allocation, and 
POSTPRINT: Inclusive education policy provision in South African research universities

changes in social and attitudinal barriers in order to embrace diversity and difference.

Descriptions of the indicators that were ambiguous were revised to fit the description of the marker. A second round of review included a blind allocation of the revised 17 indicators (to be used as codes) to the five markers, and changes were made to the coding manual accordingly.

\section{Coding}

Following the final agreement of the coding system by the three authors, concurrent coding of policies took place. The use of a predefined coding system for the analysis increased the procedural integrity of the coding process as it allowed for coding not to drift (Braun and Clarke 2006). Furthermore, Saldana (2009) described the use of collaborative coding as a notion of justification for an in-depth interpretation of data. Each numbered text segment within the policy was allocated one code. In some cases, when a numbered segment was lengthy and clearly referred to more than one code, it was further divided into codable units, each then being allocated to one code. Responses were compared and when disagreement arose, these were discussed to reach a resolution by consensus. This allowed for rigor to be demonstrated during the thematic analysis process (Braun and Clarke 2006).

\section{Results}

Results are presented in this section by describing and comparing findings regarding provisions contained in disability policies of research intensive universities in South Africa. Table 1 indicates the extent to which tier 1 research intensive universities have addressed the 17 indicators in their disability policies for an inclusive higher education for students with disabilities. Specific provisions being addressed in the policy are marked with an " $\mathrm{x}$ ". 
POSTPRINT: Inclusive education policy provision in South African research universities

Table 1. Disability policy provisions of South African tier 1 research intensive universities

\begin{tabular}{|c|c|c|c|c|c|c|}
\hline Code & Theme & $\begin{array}{r}\text { Univ } \\
1 \\
\end{array}$ & $\begin{array}{r}\text { Univ } \\
2 \\
\end{array}$ & $\begin{array}{r}\text { Univ } \\
3 \\
\end{array}$ & $\begin{array}{r}\text { Univ } \\
4 \\
\end{array}$ & $\begin{array}{r}\text { Univ } \\
5\end{array}$ \\
\hline $\begin{array}{l}\text { 1. Disability unit must be made } \\
\text { available at institutions }\end{array}$ & Availability & $\mathrm{X}$ & $\mathrm{X}$ & $\mathrm{X}$ & $\mathrm{X}$ & $\mathrm{X}$ \\
\hline $\begin{array}{l}\text { 2. All eligible students with disabilities } \\
\text { can apply to study at the institution. }\end{array}$ & Availability & $\mathrm{X}$ & $\mathrm{X}$ & $\varnothing$ & $\mathrm{X}$ & $\mathrm{X}$ \\
\hline $\begin{array}{l}\text { 3. University is accessible without } \\
\text { discrimination. }\end{array}$ & Accessibility & $\mathrm{X}$ & $\varnothing$ & $\mathrm{X}$ & $\mathrm{X}$ & $\mathrm{X}$ \\
\hline $\begin{array}{l}\text { 4. University must be physically } \\
\text { accessible. }\end{array}$ & Accessibility & $\varnothing$ & $X$ & $X$ & $\mathrm{X}$ & $X$ \\
\hline $\begin{array}{l}\text { 5. Students with disabilities have the } \\
\text { right to full and equal participation } \\
\text { to access the academic environment } \\
\text { of the university. }\end{array}$ & Accessibility & $\mathrm{X}$ & $\mathrm{X}$ & $\mathrm{X}$ & $\mathrm{X}$ & $\mathrm{X}$ \\
\hline $\begin{array}{l}\text { 6. Students with disabilities have the } \\
\text { right to full and equal participation } \\
\text { to access the social environment of } \\
\text { the university. }\end{array}$ & Accessibility & $\mathrm{X}$ & $\mathrm{X}$ & $\mathrm{X}$ & $\mathrm{X}$ & $\varnothing$ \\
\hline $\begin{array}{l}\text { 7. Removal of social and attitudinal } \\
\text { barriers that lead to discrimination }\end{array}$ & Accessibility & $\mathrm{X}$ & $\mathrm{X}$ & $\varnothing$ & $\mathrm{X}$ & $\mathrm{X}$ \\
\hline $\begin{array}{l}\text { 8. Students with disabilities provided a } \\
\text { platform to voice their individual } \\
\text { needs. }\end{array}$ & Acceptability & $\mathrm{X}$ & $\mathrm{X}$ & $\mathrm{X}$ & $\mathrm{X}$ & $\mathrm{X}$ \\
\hline $\begin{array}{l}\text { 9. Students with disabilities must be } \\
\text { accepted as a part of the university's } \\
\text { student population and not } \\
\text { segregated. }\end{array}$ & Acceptability & $\mathrm{X}$ & $\varnothing$ & $\mathrm{X}$ & $\mathrm{X}$ & $\varnothing$ \\
\hline $\begin{array}{l}\text { 10. Effective individualised support } \\
\text { measures are provided in } \\
\text { environments that maximise } \\
\text { academic and social development. }\end{array}$ & Adaptability & $\mathrm{X}$ & $\mathrm{X}$ & $\mathrm{X}$ & $\mathrm{X}$ & $\mathrm{X}$ \\
\hline $\begin{array}{l}\text { 11. The University is willing to adapt its } \\
\text { instructional techniques in } \\
\text { accordance with universal design. }\end{array}$ & Adaptability & $\mathrm{X}$ & $\varnothing$ & $\varnothing$ & $\mathrm{X}$ & $\mathrm{X}$ \\
\hline $\begin{array}{l}\text { 12. The University is willing to adapt its } \\
\text { assessment opportunities in } \\
\text { accordance with universal design. }\end{array}$ & Adaptability & $\varnothing$ & $\varnothing$ & $\varnothing$ & $\mathrm{X}$ & $\mathrm{X}$ \\
\hline $\begin{array}{l}\text { 13. The University is willing to adapt its } \\
\text { support systems/structures. }\end{array}$ & Adaptability & $\varnothing$ & $\varnothing$ & $\varnothing$ & $\varnothing$ & $\mathrm{X}$ \\
\hline $\begin{array}{l}\text { 14. The University is willing to adapt its } \\
\text { curriculum in accordance with } \\
\text { universal design. }\end{array}$ & Adaptability & $\mathrm{X}$ & $\varnothing$ & $\varnothing$ & $\mathrm{X}$ & $\mathrm{X}$ \\
\hline $\begin{array}{l}\text { 15. Disregard of reasonable } \\
\text { accommodation as a financial } \\
\text { burden }\end{array}$ & Affordability & $\varnothing$ & $\varnothing$ & $\varnothing$ & $\varnothing$ & $\varnothing$ \\
\hline $\begin{array}{l}\text { 16. Ensure that there are sufficient funds } \\
\text { made available to sustain an } \\
\text { inclusive educational system. }\end{array}$ & Affordability & $\varnothing$ & $\mathrm{X}$ & $\varnothing$ & $\mathrm{X}$ & $\mathrm{X}$ \\
\hline $\begin{array}{l}\text { 17. Economic accessibility to } \\
\text { educational institutions }\end{array}$ & Affordability & $\varnothing$ & $\varnothing$ & $\varnothing$ & $\varnothing$ & $\mathrm{X}$ \\
\hline
\end{tabular}


POSTPRINT: Inclusive education policy provision in South African research universities

Results indicate that due regard is given to availability in disability policy provisions of research intensive universities. All disability policies state that eligible students with disabilities can apply to these universities without restriction. Moreover, disability units have been established at these universities. However, only University 5 considered the historical disadvantages experienced by students with disabilities. This university made provision for offering "access programs for people from designated equity groups, including students with disabilities" (University 5).

In line with the Constitution of South Africa (1996), research intensive universities address the importance of non-discrimination and inclusion of students with disabilities and make provisions for this in their policies (access). However, universities generally qualify this access, for example, by phrases such as "Students with disabilities will have access to recreation and sport facilities on campus as far as feasible and affordable.” (University 2).

Results further indicate that overall research intensive universities make provision for the acceptance and recognition of students with disabilities as a part of the university community by indicating a willingness to engage with students with disabilities (to hear the student voice acceptability). This was indicated by phrases such as, "The University recognises the importance of consultation with people with disabilities in all decisions that affect their opportunity for full participation in University life" (University 5).

The analysis indicated that adaptability is not consistently mandated in disability policies of research intensive universities, with UDL principles not being uniformly addressed. University 2 and 3 does not recognise UDL principles to develop instruction to meet the diverse needs of every student. Furthermore, for University 1, 2 and 3, assessment opportunities are not replaced by multiple forms of assessment in accordance with UDL principles. Universities 1, 2, 
POSTPRINT: Inclusive education policy provision in South African research universities

3, 4 and 5 all indicate that where adaptation or specialised design is required in terms of reasonable accommodation, the institution reserves the right to utilise lack of resources as a justification for failure to provide a request for reasonable accommodation.

Across research intensive universities, due regard is not given to affordability in policy provisions. Results indicate that only University 4 and 5 make provision for resources to be made available to sustain an inclusive higher education system. Furthermore, only University 5 makes provision for the economic accessibility to educational services provided by the university:

There shall be a special budget, within available resources, for the implementation of support services for students and staff with disabilities administered by the Disability Management Committee. This budget shall cater for equipment, furniture, access, capital building projects and academic development. (University 5)

Results further indicate that none of the universities disregard reasonable accommodation as a financial burden. On the contrary, the affordability (for the university) of inclusive measures seems to be held up as a condition upon which the inclusion of students with disabilities rests. Universities therefore disclaim responsibility for ensuring that the educational opportunities offered at their institutions are affordable for students with disabilities, and instead, qualify their own financial commitment in this regard.

Universities state the following regarding policy provisions and affordability: “...does not cause the University unjustifiable hardship and does not impose a disproportionate or undue burden on the University." (University 4) “...will incrementally remove or limit any barrier impacting on students with disabilities as far as is reasonable practicable and financially affordable to do so." (University 4) 
POSTPRINT: Inclusive education policy provision in South African research universities

“...provision of appropriate support where needed in a particular case will be limited by the affordability of those support systems and with due regard for the current and future financial constraints of the University.” (University 1)

"This policy aims to provide specially adapted facilities for the needs of students with special learning needs/disabilities, within limits of reason, and taking financial restraints into consideration.” (University 3)

In general, policies made mention of provisions related to availability, accessibility and acceptability. Provisions related to adaptability were not uniformly mentioned in all policies. Affordability as a policy provision for the inclusion of students with disabilities was neglected and not given due regard. Furthermore, various conditions and qualifications relating to availability, accessibility, acceptability, adaptability and affordability suggest that inclusion of students with disabilities is narrowly envisioned as dependent on the university's economic capacity. Lastly, provisions in university policies lack timeframes and the implementations of the policies are not time bound.

In summary, results showed that provisions within disability policies of South African tier 1 research intensive universities are multifaceted and involve most dimensions of inclusive education. However, policy gaps are noted in the provision of resources to sustain an inclusive higher education system.

\section{Discussion}

The discussion takes into consideration literature on each marker of inclusive higher education for students with disabilities within a human rights framework and draws comparison on policy 
POSTPRINT: Inclusive education policy provision in South African research universities

provisions and gaps. The implications of the findings of this study are intended to augment the understanding of disability policy provisions of research intensive South African universities and the degree to which these policies adequately embody the five markers of inclusive education.

South Africa has a progressive legal and policy framework where the right to education for students with disabilities is protected. Therefore, students with disabilities should be ensured the incontestable and unambiguous right to access education on an equal basis with other members of society. In the interpretation of the results it was evident that South African tier 1 research intensive universities have responded to national efforts towards an inclusive education system. Research intensive universities have all drafted disability policies to ensure the inclusion of students with disabilities at their individual institutions. The five markers of inclusive education are presented individually below, to allow for an in-depth discussion of each and to highlight policy provisions and gaps.

\section{Availability}

The marker of availability in disability policies accounts for the extension of the right to education for students with disabilities at a tertiary level and prevents discrimination. The finding that the theme of availability is adequately addressed is consistent with a considerable body of literature that indicates that there is a growing commitment to include students with disabilities in higher education (FOTIM 2011; Fuller, Healey, Bradley and Hall 2004; Lourens 2015; Ntombela 2013). However, many of these students are required, as per policy, to submit medical proof to verify any impairment or condition claimed. Howell and Lazarus (2003) postulate that the dominant medical discourse of disability and the emphasis placed on individual deficit influences the provision of support to students with disabilities at South African higher education 
POSTPRINT: Inclusive education policy provision in South African research universities

institutions. This is contrary to Bell (2013), who postulated that the social model of disability has informed the development of inclusive education policies in South Africa. Thus, it can be assumed that while students with disabilities who meet the academic requirements are accepted into the university, their full integration into the university community is dependent on the university's understanding of the particular impairment. A medical diagnosis of disability remains predominant when ensuring the inclusion of students with disabilities. This understanding of disability at university sets the parameter for the university's response to including students with disabilities.

As with national legislature and policy frameworks that seek to address the injustices that were sanctioned by the Apartheid government based on race, gender and disability, research intensive universities should prioritise the inclusion of previously disadvantaged groups of society, including students with disabilities. The selectivity of the basic education system in South Africa in favour of ableism and against students with disabilities is a major contributing factor towards limited access to higher education institutions for these students (Howell and Lazarus 2003). Mayer (2005) raises concerns that this selectivity results in a cycle of cumulative disadvantage. Thus, due to discriminatory practices and attitudes within the basic education system, students with disabilities are therefore unlikely to access or have very limited access to higher education institutions. Brabazon (2015) points that this scale of oppression must be addressed by policies of higher education institutions. University 5 was exemplary in terms of considering the historical disadvantages experienced by students with disabilities by offering “access programs for people from designated equity groups, including students with disabilities". It is of paramount importance that universities consider the historical disadvantages experienced by students with disabilities not only based on their disability but race and gender as well - 
POSTPRINT: Inclusive education policy provision in South African research universities

factors which have been termed as the double and triple burden of disability. This ensures that students with disabilities are not excluded due to belonging to more than one marginalised group. Therefore, previously white institutions, lack policy provisions that allow for the evaluation of social barriers to education.

While all stakeholders are responsible for the inclusion of students with disabilities, disability units play a crucial role at universities as they are intended to be custodians of the disability policy of their respective institutions. A key feature of availability is for disability units to be established at universities, as they play a central role in the inclusion of students with disabilities without restriction at these institutions (Lourens 2015; Matshedisho 2010). Although all five universities make provision in their policies for disability units, services of these units are dependent on resource constraints. In a study that examined South African higher education institutions, findings indicated that the services offered by these disability units and the resources available to them for service delivery are reliant on buy-in from senior management (FOTIM 2011). We therefore postulate that, if resource allocation to disability units is not regarded as an essential feature by senior management, institutions only pay lip service to inclusion of students with disabilities. Consequently, if there is lack of support from senior management and management reduces the budget of disability units, this has a negative impact on the type and level of support provided to students with disabilities, as there may be insufficient financial and human resources to provide effective services. This ultimately hampers equal participation of students with disabilities in the university environment, including successful and timely graduation. 
POSTPRINT: Inclusive education policy provision in South African research universities

\section{Accessibility}

Accessibility is based on the principle of non-discrimination and inclusion (Tomaševski 1999). Furthermore, accessibility is precondition for the full and equal participation of students with disabilities in their academic environments (UN 2014, 2016). Therefore, institutions must prohibit discrimination against students with disabilities. Results show that the five universities prohibit discrimination against students with disabilities once they are granted admission to enrol for a degree based on their right to full and equal participation, allowing access to the academic and social environment of the university.

Despite certain policy provisions pertaining to both the academic and social environment, access to the social environment is limited in terms of housing, recreation and sport facilities on campus, as it will only be considered as far as it is feasible and affordable to the university. This substantially limits opportunities to access social learning opportunities. Article 30 of the CRPD (UN 2006) highlights the importance of the participation of persons with disabilities in cultural life, recreation, leisure and sport. It clearly states that measures must be taken to ensure equal participation to social life on equal basis with others. Therefore, we concur that equal access to social learning opportunities must be provided for in disability policies without restriction, as access to the social environment allows for the holistic development of students with disabilities. Opportunities to develop socials skills have further benefit for their integration into society and industry once they successfully graduate from the institution.

Howell and Lazurus (2003) found that prevailing attitudes and prejudices towards students with disabilities by higher education institutions have a sustained effect on the psychological well-being and functioning of the student. This finding is corroborated by Banks (2008, p. 7), who postulates that “...policies of inclusion have the potential to reduce negative 
POSTPRINT: Inclusive education policy provision in South African research universities

attitudes towards persons with disabilities...”. Research intensive universities have recognised this barrier and provisions are made in their policies to limit attitudinal barriers that students with disabilities may experience. In explicitly preventing attitudinal barriers at policy level, research intensive institutions proactively incorporate the rights of students with disabilities to be included within its student body and academic environment. This ensures a non-tolerance towards attitudinal barriers.

While Universities 2, 3, 4 and 5 allocate provisions for the institution to be physically accessible, University 1 does not address physical accessibility in its disability policy. Furthermore, University 2 points out that it "faces particular challenges providing access to the built environment for people with disabilities" and "will identify, and where possible, address barriers to facilities at the University". The National Development Plan (NDP) (National Planning Commission 2012), approved by the South African government in 2012, acknowledged that persons with disabilities are not able to achieve their full potential if physical, information, communication and attitudinal barriers are not addressed. Based on the NDP, it can be assumed that a physically accessible university environment contributes towards students with disabilities achieving their full academic potential. Universities 2, 3 and 4 address only the infrastructural aspects of physical accessibility of their buildings and fail to address other changes to the physical environment that are required, for instance, Braille signage across campuses. Without effective signage, universities are inaccessible to students with sensory disabilities as well as learning disabilities. Furthermore, if an institution makes provision for the accessibility of its environments by implementing universal design principles (Department of Social Development 2015), it ensures the safety, security and well-being of all students with disabilities on its premises. Universities should take a critical appraisal of physical accessibility and consider all 
POSTPRINT: Inclusive education policy provision in South African research universities categories of disability and all environments, including student transport, residences, effective signage, and evacuation procedures. As students with disabilities often encounter barriers to physical access, addressing this at policy level will foster the participation of students with disabilities and reinforce inclusive practices.

\section{Acceptability}

The marker of acceptability brings together elements of acceptance and recognition of the student voice. Results indicate that, overall, research intensive institutions make provision towards ensuring that the student voice is heard. Tinklin et al., (2004) postulate that a platform for the voices of students with disabilities is seldom found in inclusive policies and practices. Fuller, Bradley and Healey (2015), in their investigation of the incorporation of students with disabilities within an inclusive higher education environment in the UK, argued that despite the growing interest in inclusive higher education, "the voices of students with disabilities themselves have barely been heard" (p. 1). This underscores the importance of policy provisions to provide a platform for the voice of students with disabilities to be heard. South African universities recognise the importance of openness to engage in dialogue with their students with disabilities. This may allow for a comprehensive understanding of students with disabilities, valuable insight and input from a diverse group of students, and the opportunity for these students to self-advocate.

\section{Adaptability}

Adaptability requires the institution apply the Universal Design for Learning (UDL) approach (UN, 2016). This marker encompasses both the need to comply with the principles for universal 
POSTPRINT: Inclusive education policy provision in South African research universities design and also provide reasonable accommodation where specialised adaption is required. According to the general comments on Article 9 (United Nations 2014) and Article 24 (United Nations 2016) of the CRPD, universal design broadly ensures that all students can benefit from services. It is therefore imperative that universities incorporate the principles of universal design into their curricula, instructional design, assessment measures, use of various technologies, and support structures. This ultimately benefits all students, including students with disabilities. Adherence to universal design standards is mandatory and may not be made contingent upon available resources (UN 2014).

Reasonable accommodation, on the other hand, is a strategy aimed at adapting services for an individual, over and above the principles of universal design. Article 24 of the CRPD defines reasonable accommodation as a

"necessary and appropriate modification and adjustments not imposing a disproportionate or undue burden, where needed in a particular case, to ensure to persons with disabilities the enjoyment or exercise on an equal basis with others of all human rights and fundamental freedoms (United Nations 2006, p. 4).”

It is clear that the provision of reasonable accommodation is therefore conditional.

Results pertaining to adaptability show that universities 1,4 and 5 have made a commitment to adapt their curriculum in accordance with universal design for learning. Adaption of the curriculum is essential for all students including students with disabilities to access learning material required in order to equally participate in the learning experience. Research intensive universities differ when it comes to adapting assessment opportunities. Universities 4 and 5 make provision for UDL principles to be applied adapting their assessment opportunities, while Universities 1,2 and 3 do not. Assessment opportunities are factual 
POSTPRINT: Inclusive education policy provision in South African research universities

evidence of a student's academic ability. Assessment opportunities are also an important aspect of the teaching and learning process. Lack of provision in policies for flexibility of assessment opportunities negates any support provided in the teaching and learning environment. A holistic understanding of this process is required to ensure that students with disabilities are provided equal opportunities to have their academic abilities assessed. Liberal and previously disadvantaged institutions therefore recognise the importance of replacing standardised assessments in recognition of individual progress towards broad goals of academic achievement.

The adaptation of support structures (e.g., library access, student counselling and graduate recruitment programmes) was less frequently addressed in the policies - only Universities 3 (previously white) and 5 (previously disadvantaged) addressed this indicator in their policies. The barriers as experienced by students with disabilities relating to the provision of learning support, substantially limit the ability of these students to participate equitably (CHE 2001; Howell and Lazurus 2003). Universities 3 and 5 recognise the importance of adapting their support structures and provide for opportunities for academic, career, and personal development. Providing for the adaption of support structures is necessary for the holistic development of students with disabilities. More emphasis should be placed by research intensive institutions on promoting equal access for students with disabilities to their support structures.

Furthermore, all disability policies make provision for individualised support measures in environments that maximise academic and social development (reasonable accommodation). However, all institutions state that they may decline a request for reasonable accommodation if it causes unjustifiable hardship to the institution.

The question arises as to what constitutes such 'unjustifiable hardship' or as stated in the CRPD, 'disproportionate or undue burden. Currently, policies and the CRPD leave this open to 
POSTPRINT: Inclusive education policy provision in South African research universities

interpretation. There are limited imperatives delineating requirements for reasonable accommodation. Should a university face obstacles to inclusion relating to a lack of resources and lack of support from senior management, students with disabilities are likely to be inadequately accommodated. This will result in a negative effect on students achieving their educational outcomes.

\section{Affordability}

Affordability refers to the economic accessibility to educational services provided by the institution. Results indicate that in terms of affordability, only Universities 2 (previously white) and 5 (previously disadvantaged) make provision for resources to be made available to sustain an inclusive education system. Furthermore, only University 5 makes provision for the economic accessibility to educational services provided by the university. Results further indicate that none of the universities disregard reasonable accommodation as a financial burden. Whilst the CRPD (2006) allows for financial implications to be recognized when assessing disproportionate burden, it asserts that this cannot be used as a justification for failure to fulfil a request for reasonable accommodation.

The FOTIM (2011) research showed that current funding is not adequate as students with disabilities pay personally to address the needs (ICT, South African Sign Language interpreters, assistive devices), that disability allowances cover in other countries. Students with disabilities have the right to affordable access to education. We recommend that sufficient funding, budgeting processes and commitment from senior management in the allocation of funding be secured. Thus, a funding model needs to be developed as part of policy to address the economic accessibility of universities. 
POSTPRINT: Inclusive education policy provision in South African research universities

As tertiary education in South Africa is a progressive right, the reasonable accommodation of students with disabilities can be viewed equally so. Chenwi (2013) unpacked the progressive realisation, its relation to resources, minimum core and reasonableness, and some methodological considerations for assessing compliance to socio-economic rights in South Africa as stated in the International Covenant on Economic, Social and Cultural Rights (ICESCR) (UN, 1966). She explains that "the progressive realisation qualification requires a country to strive towards fulfilment and improvement in the enjoyment of socio-economic rights to the maximum extent possible, even in the face of resource constraints" (p. 743).

With regards to all education systems, Chenwi (2013) postulates that: "In relation to the right to education, for example, there is less flexibility. States have an obligation to adopt a plan of action within a reasonable number of years and the timeframe must be fixed in the plan... The steps taken must be effective and not be of negligible impact. Thus, it should not take an unreasonable amount of time to create effects" (p. 744)

Therefore, in applying the above to higher education in South Africa and considering the lack of policy to guide higher education policies, universities and government should, in their policies, make provision for the progressive realisation of an affordable and economically accessible inclusive education system as evidenced by the policy provisions made by University 5. University 5 commits in its policy to providing budget to academic and support departments as well as making financial aid opportunities available to increase access to higher education for affected students.

Many of the provisions relating to affordability in university policies lack timeframes and appear to be indefinite. Universities should not escape the obligation to provide support to 
POSTPRINT: Inclusive education policy provision in South African research universities

students with disabilities on the grounds that the necessary resources are not available. The lack of financial resources hinders the realisation of the right to education at a tertiary level for students with disabilities. The progressive realisation of this right should be time bound and prioritised.

\section{Conclusion}

South Africa has progressive legislature and policy frameworks pertaining to inclusive education at a basic education level. However, there is a lack of a unified comprehensive policy framework to guide inclusive higher education disability policy provisions to support students with disabilities. Despite this gap, the policies of tier 1 research intensive universities address four of the five markers of inclusive higher education, namely availability, accessibility, acceptability, and adaptability. By comparison, affordability for the inclusion of students with disabilities is neglected. Furthermore, policy provisions that are addressed are often conditional, preventing the policy from taking full effect. The provisions of a disability policy are the cornerstone of inclusive higher education and gaps in these provisions result in students with disabilities being excluded and ultimately denied their right to an inclusive higher education system. Provisions in disability policies of universities must ensure that all academically suitable students with disabilities are given an equal opportunity to enter the higher education system. In some cases, universities may even be called on to attempt to redress inequities in the basic education system through bridging programs that allow students to prove themselves 'academically suitable'. Furthermore, provisions should address the removal of discriminatory barriers to access and ensure that universal design informs access and equal participation. Economic accessibility must be viewed as a priority in sustaining an inclusive higher education 
POSTPRINT: Inclusive education policy provision in South African research universities system. The progressive realisation of inclusion of students with disabilities must be clearly articulated in disability policies to ensure the fulfilment of the right to education at a tertiary level. Lastly, it is imperative that the South African government take the appropriate measures to ensure the inclusion of students with disabilities at a tertiary level. This necessitates the development of a national policy framework as well as legislature for this sector, but also urgent interventions that will ensure that the right to appropriate and high quality basic education for children with disabilities is met (Human Rights Watch, 2015)

\section{Limitations}

The scope of this study is limited to tier 1 research intensive institutions in South Africa. Thus, findings are not generalisable to other higher education institutions in the country.

This study utilised a deductive (theoretical) thematic analysis. Therefore, the authors' analytic preconceptions and theoretical interests may have influenced analysis, as opposed to an inductive approach, where the themes identified would be more strongly linked to the data.

Furthermore, the scope of this article focussed only on policy provisions of disability policies in tier 1 South African research intensive universities and did not include an analysis of policy implementation.

\section{Recommendations for further studies}

Despite some limitations to this study, it does present with avenues for further research. An understanding of policy provisions and gaps for all 26 higher education institutions in the country is required. A larger sample size will allow for a comprehensive understanding of disability policies in South African universities. 
POSTPRINT: Inclusive education policy provision in South African research universities

Policy implementation is binary to the provisions developed within a policy. A qualitative exploration of the disability policy implementation at universities in South Africa will indicate whether policy provisions are implemented successfully or not (i.e. are policies contributing towards or hindering the inclusion of students with disabilities at universities?). This qualitative exploration should also include staff perceptions (academic and support). This indepth exploration will inform future policy development and a policy framework for inclusive higher education.

Lastly, the analysis of policies should encompass diverse methodological approaches. It is further recommended that future studies embark on a critical discourse analysis of disability policies to unpack ideologies of higher education policies.

\section{References:}

Arendse, L. 2011. "The Obligation to Provide Free Basic Education in South Africa: An International Law Perspective.” Potchefstroom Electronic Law Journal 14 (6): 97-127.

Banks, Christina M. 2008. "Creating Positive Attitudes toward People with Disabilities through Inclusion." Hanover College.

Beauchamp-Pryor, Karen. 2012. "From Absent to Active Voices: Securing Disability Equality within Higher Education." International Journal of Inclusive Education 16 (3): 283-95. doi:10.1080/13603116.2010.489120.

Bell, Diane. 2013. "Investigating Teaching and Learning Support for Students with Hearing Impairment at a University in the Western Cape." Stellenbosch University. http://scholar.sun.ac.za/handle/10019.1/80004.

Biermann, Julia. 2016. "Approaches to Inclusive Education in Nigeria: The Pivotal Role of Poverty and Disability." Zeitschrift Für Inklusion [Journal for Inclusion], no. 1. https://www.inklusion-online.net/index.php/inklusion-online/article/view/338.

Brabazon, Tara. 2015. Enabling University: Impairment, (Dis)ability and Social Justice in Higher Education. SpringerBriefs in Education. Cham: Springer International Publishing. doi:10.1007/978-3-319-12802-3.

Braun, Virginia, and Victoria Clarke. 2006. "Using Thematic Analysis in Psychology." Qualitative Research in Psychology 3 (2): 77-101. doi:10.1191/1478088706qp063oa.

Carrim, Nazir. 2002. "Inclusion/exclusion in South African Education." Learning about Inclusion and Exclusion in Education Policy and Implementation in India and South Africa, Education Institute of Development Studies, Discussion Paper, No. 2. Sussex.

Cartwright, Nathaniel Knox, and Petros Carvounis. 2005. Short Answer Questions for the MRCOphth Part 1. Oxford: Radcliffe Publishing. 
POSTPRINT: Inclusive education policy provision in South African research universities

Cebekhulu, Elias, and Evan Mantzaris. 2006. "Stop Beating the Bush - the UKZN Merger: A Tragic Mishap.” Alternation 13 (1): 88-106.

Centre for Higher Education Transformation (CHET). 2013. 2013 South African Higher Education: Key Statistics. Pretoria: CHET.

Chenwi, Lillian. 2013. 'Unpacking 'progressive Realisation', Its Relation to Resources, Minimum Core and Reasonableness, and Some Methodological Considerations for Assessing Compliance." De Jure 46 (3): 742-69.

Chetty, Nithaya, and Christopher Merrett. 2014. The Struggle for the Soul of a South African University: The University of KwaZulu-Natal: Academic Freedom, Corporatisation and Transformation.

Council on Higher Education (CHE). 2010. Annual Report 2009 -2010. Pretoria.

Department of Education (DoE). 1997. Education White Paper 3: A Programme for Transformation of Higher Education. Pretoria: Government Printer.

Department of Higher Education and Training (DHET). 2001. National Plan for Higher Education. Pretoria: Government Printer.

Department of Higher Education and Training (DHET). 2013. White Paper for Post-School Education and Training. Pretoria: Government Printer.

Department of Higher Education and Training (DHET). 2015. Annual Report 2014/2015. Pretoria: Government Printer.

Department of Social Development. 2015. White Paper on the Rights of Persons with Disabilities. Pretoria: Government Printer.

Donohue, Dana K., and Juan Bornman. 2014. "The Challenges of Realising Inclusive Education in South Africa." South African Journal of Education 34 (2): 1-14.

Eide, AH., M.E. Loeb, S. Nhiwatiwa, A. Munthali, T.J. Ngulube, and G. van Rooy. 2011. "Living with Conditions among People with Disabilities in Developing Countries." In Disability and Poverty, 55-71. Bristol: The Policy Press.

Fitchett, A. 2015. "Exploring Adaptive Co-Management as a Means to Improving Accessibility for People with Reduced Mobility at the University of Witwatersrand.” In Making Education Inclusive., edited by E. Walton and S Moonsamy, 130-46. Newcastle: Cambridge Scholars Publishing.

Foundation of Tertiary Institutions of the Northern Metropolis. 2011. "Disability in Higher Education, Project Report.” doi:10.1787/9789264105072-en.

Fuller, Mary, Andrew Bradley, and Mick Healey. 2004. "Incorporating Disabled Students within an Inclusive Higher Education Environment." Disability \& Society 19 (5): 455-68. doi:10.1080/0968759042000235307.

Fuller, Mary, Mick Healey, Andrew Bradley, and Tim Hall. 2004. "Barriers to Learning: A Systematic Study of the Experience of Disabled Students in One University." Studies in Higher Education 29 (3): 303-18. doi:10.1080/03075070410001682592.

Heiman, Tali, and Karen Precel. 2003. "Students with Learning Disabilities in Higher Education: Academic Strategies Profile.” Journal of Learning Disabilities 36 (3): 248-58. doi:10.1177/002221940303600304.

Howell, Colleen. 2001. "Disabled Students and Higher Education in South Africa." In Disability and Social Change: A South African Agenda, edited by Marguerite Schneider and Mark Priestley Brian Watermeyer, Leslie Swartz, Theresa Lorenzo, 164-78. Cape Town: HSRC Press.

Howell, Colleen, and Sandy Lazarus. 2003. "Access and Participation for Students with 
POSTPRINT: Inclusive education policy provision in South African research universities

Disabilities in South African Higher Education: Challenging Accepted Truths and Recognising New Possibilities." Perspectives in Education 21 (3): 59-74. http://0reference.sabinet.co.za.innopac.up.ac.za/webx/access/electronic_journals/persed/persed_v2 1_n3_a7.pdf.

Human Rights Watch. 2015. "Complicit in Exclusion” South Africa's Failure to Guarantee an Inclusive Education for Children with Disabilities. http://www.heartresources.org/doc_lib/complicit-in-exclusion-south-africas-failure-to-guarantee-aninclusive-education-for-children-with-disabilities/.

Klees, Steven J., and Thapliyal, Nisha 2007. "Education Denied: Costs and Remedies by Katarina Tomasevski; Human Rights Obligations in Education: The 4-A Scheme by Katarina Tomasevski; 'The State of the Right to Education Worldwide: Free or Fee; 2006 Global Report' by Katarina Tomasevski." Comparative Education Review 51 (4): 497-510. doi:10.1086/520863.

Lourens, Heidi. 2015. "The Lived Experiences of Higher Education for Students with a Visual Impairment: A Phenomenological Study at Two Universities in the Western Cape, South." PhD diss., Stellenbosch Univeristy. http://scholar.sun.ac.za/handle/10019.1/96732.

Matshedisho, K R. 2007. "The Challenge of Real Rights for Disabled Students in South Africa." South African Journal of Higher Education 21 (4): 706-16.

Matshedisho, K R. 2010. "Experiences of Disabled Students in South Africa : Extending the Thinking behind Disability Support." South African Journal of Higher Education 24 (5): 730-44. http://0-reference.sabinet.co.za.innopac.up.ac.za/document/EJC37645.

Maxwell, Gregor, and M. Granlund. 2011. "How Are Conditions for Participation Expressed in Education Policy Documents ? A Review of Documents in Scotland and Sweden." European Journal of Special Needs 26 (2): 251-72. doi:10.1080/08856257.2011.563610.

Mayer, Karl Ulrich. 2005. "Life Courses and Life Chances in a Comparative Perspective." In Analyzing Inequality, edited by Stefan Svallfors, 17-55. Standford, CA: Standford University Press.

McLaren, P, Geoff Solarsh, and Gillian Saloojee. 2003. "Disability and Disablement." South African Health Review 12: 163-73.

Murungi, Lucyline Nkatha. 2013. "The Significance of Article 24(2) of the UN Convention on the Rights of Persons with Disabilities for the Right to Primary Education of Children with Disabilities: A Comparative Study of Kenya and South Africa." PhD diss., University of the Western Cape.

National Planning Commission. 2012. National Development Plan 2030. Our Future - Make It Work. Pretoria: Government Printer.

Ndlovu, Sibonokuhle. 2016. "Preparation of Students with Disabilities to Graduate into Professions in the South African Context of Higher Learning : Obstacles and Opportunities." African Journal of Disability 5 (1): 1-8. doi:. http://dx.doi. org/10.4102/ajod.v5i1.150.

Ntombela, Sithabile. 2013. "Inclusive Education and Training in South African Higher Education : Mapping the Experiences of a Student with Physical Disability at University. Africa Education Review, 10(3), 483-501. doi:10.1080/18146627.2013.853541.

Oliver, Michael. 1996. Understanding Disability: From Theory to Practice. New York: St Martin's Press.

Pather, Sulochini. 2011. "Evidence on Inclusion and Support for Learners with Disabilities in Mainstream Schools in South Africa: Off the Policy Radar?” International Journal of 
POSTPRINT: Inclusive education policy provision in South African research universities

Inclusive Education 15 (10): 1103-17. doi:10.1080/13603116.2011.555075.

Powell, Justin J W. 2013. "From Ableism to Accessibility in the Universal Design University." Review of Disability Studies: An International Journal 8 (4): 33-45.

Saldana, Johnny. 2009. The Coding Manual for Qualitative Researchers. The Coding Manual for Qualitative Researchers. London: SAGE.

Sayed, Yusuf. 2003. "Educational Exclusion and Inclusion in Higher Education in South Africa: Creating a New National Framework/consensus." In Access and Exclusion, edited by Malcolm Tight, 83-101. Oxford: Elsevier. doi:10.1016/S1479-3628(03)80006-0.

Schaeffer, Sheldon. 2009. "Realizing Inclusive Education Thorugh Applying a Rights-Based Approach Ro Education." In Defining an Inclusive Education Agenda: Reflections around the 48th Session of the International Conference on Education, edited by Clementina Acedo, Massimo Amadio, and Renato Opertti, 87-91. Geneva: UNESCO: International Bureau of Education.

Shakespeare, Tom. 1996. "Disability, Identity and Difference." In Exploring the Divide, edited by Colin Barnes and Geof Mercer, 6:94-113. Leeds: The Disability Press.

Skelton, Ann. 2013. "The Role of the Courts in Ensuring the Right to a Basic Education in a Democratic South Africa : A Critical Evaluation of Recent Education Case Law." De Jure 1 (46): 1-23.

South Africa. 1996. Constitution of the Republic of South Africa, Act No. 108 of 1996. Pretoria: Government Printer.

South Africa. 1997. Higher Education Act 101 of 1997, Pretoria: Government Printers. Pretoria: Government Printer.

Swart, Estelle, and Elsabe Greyling. 2011. "Participation in Higher Education: Experiences of Students with Disabilities." Acta Academica 43 (4): 81-110.

Tesemma, Shimelis Tsegaye. 2012. "A Critical Analysis of Law and Policy on the Education of Disabled Children in South Africa." University of South Africa.

Times Higher Education. 2017. "Times Higher Education Data Points: Helping Universities Improve through Performance Analysis and Benchmarking."

https://www.timeshighereducation.com/sites/default/files/the_datapoints_brochure_cropmar $\mathrm{k}$ free.pdf.

Tinklin, Teresa, Sheila Riddell, and Alastair Wilson. 2004. "Policy and Provision for Disabled Students in Higher Education in Scotland and England: The Current State of Play." Studies in Higher Education 29 (5): 637-57. doi:10.1080/0307507042000261599.

Tisdall, E. Kay M., and Sheila Riddell. 2006. "Policies on Special Needs Education: Competing Strategies and Discourses.” European Journal of Special Needs Education 21 (4): 363-79. doi:10.1080/08856250600956154.

Tomaševski, Katarina. 1999. "Preliminary Report of the Special Rapporteur on the Right to Education, Ms. Katarina Tomasevski, Submitted in Accordance with Commission on Human Rights Resolution 1998/33."

Tomaševski, Katarina. 2001. Human Rights Obligations : Making Education Available, Accessible, Acceptable and Adaptable. Right to Education Primers no.3. http://www.rightto-education.org/sites/right-to-education.org/files/resource-attachments/Tomasevski_Primer 3.pdf.

Tomaševski, Katarina. 2004. Manual on Rights-Based Education:global Human Rights Requirements Made Simple. Bangkok: UNESCO Asia and Pacific Regional Bureau for Education. 
POSTPRINT: Inclusive education policy provision in South African research universities

United Nations. 1948. Universal Declaration of Human Rights. New York: UN General Assembly.

United Nations. 1966. International Covenant on Economic, Social and Cultural Rights (ICESCR).

United Nations. 2006. "Convention on the Rights of Persons with Disabilities and Optional Protocol." New York.

United Nations. 2014. "Convention on the Rights of Persons with Disabilities, General Comment No. 2 (2014) Article 9: Accessibility."

United Nations (2016) Article 24: Right to Inclusive Education."

Watermeyer, Brian Paul. 2009. "Conceptualising Psycho-Emotional Aspects of Disablist Discrimination and Impairment : Towards a Psychoanalytically Informed Disability Studies."PhD diss., Stellenbosch Univeristy.

Westhuizen, E J Van Der. 2011. "Influence of a University Merger on Personnel at the University of South Africa" 33 (2): 189-204.

World Health Organisation [WHO]. 2011. World Report on Disability. http://www.who.int/disabilities/world_report/2011/report.pdf. 